\title{
PENINGKATAN POPULASI DAN PEMANFAATAN AYAM LOKAL BENGKULU MELALUI PENERAPAN TEKNOLOGI MIKRONUTRISI DAN PENETASAN SEDERHANA UNTUK PENINGKATAN PENDAPATAN MASYARAKAT
}

\section{POPULATION INCREASING AND USING OF BENGKULU'S LOCAL CHICKEN THROUGH MICRONUTRIENTS AND SIMPLE HATCHING TECHNOLOGY FOR PEOPLE'S INCOME GENERATING}

\author{
Oleh: \\ Nurmeiliasari, Heri Dwi Putranto, Urip Santoso, dan Apri Andani \\ Fakultas Pertanian Universitas Bengkulu
}

\begin{abstract}
The program aims to increase the community interest to local genetic wealth of Burgo chicken. The long term goal of this training is to make the village Sumber Rejo as centers of production, marketing and research activities of Burgo chicken. The method used in this service activity is a demonstration plot. The group is the group members who have been provided the knowledge and skills regarding the operation of the hatching machine. In the aspect of feed, farmers are given knowledge about the type of food, kathuk leaf supplement and ration formulation and feed mixing practices. This method is applied to support the acceleration of population growth of Burgo chicken. Extension and practice of using hatching machine, as well as kathuk leaf extract supplementation, also introduce to target farmer groups as a holistic effort in increasing Burgo chicken population. The implementation of this activity shows some facts that (1) Burgo chicken is relatively hard to find and can be sold at high prices. (2) During the culture treatment of feed that has been tested in previous studies, the production of eggs produced relatively high at an average of 48 eggs per head per egg-laying period, with low egg weight at an average of 35 grams per egg. (3) Power of hatching eggs based on observations is still in the good range at $41 \%$. (4) The DOC mortality rate reaches $50 \%$. Egg production data shows good potential. It can be seen from the total eggs produced within three months of culture (48 eggs) from five Burgo hens. High mortality and unmaximally hatchability will be increased along with the increasing skill in the culture farming and operation of the hatching machine.
\end{abstract}

Key words: Burgo Chicken, Hatching, Katuk Leaf Extract, Revenue

\section{PENDAHULUAN}

Ayam Burgo adalah plasma nutfah asli Bengkulu yang memiliki ciri khusus yaitu bercuping putih, ukuran serta bentuk tubuh yang unik, warna bulu yang indah suara yang yang tergolong merdu. Karakteristik ini juga menunjukkan kelebihan dan potensi yang dimiliki ayam Burgo. Berdasarkan penelitian populasi dan penyebaran ayam Burgo yang dilakukan di beberapa wilayah di Provinsi Bengkulu, disimpulkan bahwa asset daerah ini 
perlu dilestarikan dengan ditingkatkan populasi serta pemanfaatannya. Nurmeiliasari (2003) menemukan bahwa di Kecamatan Curup, populasi ayam keturunan ayam Hutan Merah ini adalah sebanyak 227 ekor. Jumlah ini adalah jumlah tertinggi jika dibandingkan jumlah populasi ayam Burgo di Kecamatan Padang Ulak Tanding, yaitu 196 ekor (Dapriansyah, 2001), di Kecamatan Kepahiang sebanyak 170 ekor (Nurmeiliasari, 2003) dan terendah yaitu di Kecamatan Lebong Utara dan Lebong Selatan yaitu masing-masing 5 ekor (Lisaudin, 2001). Hasil yang sama ditemukan oleh Putranto, dkk (2010a) yang menyimpulkan bahwa populasi ayam Burgo terbanyak adalah di Kabupaten Rejang Lebong, diikuti Kabupaten Bengkulu Tengah, Lebong, Kepahiang dan Bengkulu Tengah pada posisi terakhir. Desa Sumber Rejo-Transad, salah satu desa di Kabupaten Rejang Lebong adalah salah satu pemasok utama ayam Burgo jantan bagi masyarakat pencinta ayam hias meskipun ketidakseimbangan antara pertambahan populasi dan jumlah permintaan masyarakat menjadi rintangan dalam mempertahankan kemurniannya secara genetis dan keberadaannya sebagai ayam lokal asli Bengkulu. Penelitian Putranto, dkk (2010a) menyebutkan bahwa telah terjadi penurunan populasi yang signifikan dari kurun waktu 2001 (227 ekor) sampai 2010 (98 ekor). Rangkaian penelitian yang berjudul Kajian Konservasi: Populasi, Tampilan Reproduksi dan Potensi Domestikasi Ayam Burgo Plasma Nutfah Endemik Bengkulu telah didanai melalui Hibah Kompetitif Penelitian Strategis Nasional Batch 2 selama tiga tahun berturut-turut (2009, 2010 dan tahun ke-3 di 2011).

Berdasarkan data penelitian populasi diatas, perlu ada tindak lanjut untuk mempertahankan populasi ayam Burgo agar tetap lestari mengingat ayam Burgo adalah plasma nutfah asli Bengkulu yang merupakan sumber keanekaragaman hayati. Pada rangkaian penelitian yang sama, ditahun 2010 dilakukan kajian mengenai karakteristik reproduksi ayam Burgo betina dengan menguji efektifitas mikro nutrisi yaitu ekstrak daun katuk (EDK) yang disuplementasikan melalui pakan yang bertujuan untuk peningkatan tampilan produksi dan reproduksi ayam Burgo betina. Data dasar tentang status fisiologi reproduksi serta tampilan reproduksi ayam Burgo betina dalam upaya domestikasi dan memperbaiki populasi ayam Burgo untuk kepentingan konservasi dikumpulkan pada penelitian tahun ke-2 ini. Hasilnya menunjukkan pemberian 27 gram EDK/ekor/hari dapat meningkatkan performans reproduksi dengan konsentrasi hormon E2 dan jumlah folikel yang meningkat (Putranto, Santoso dan Nurmeiliasari, 2010b). Data ini sejalan dengan data produksi telur dan berat telur. Suplementasi EDK pada level 27 g/ekor/hari juga meningkatkan jumlah telur per periode bertelur sampai 26 butir, lebih tinggi dibandingkan kelompok kontrol yaitu 15 butir per ekor per hari. Data berat telur pada kelompok perlakuan yang sama juga meningkat hingga 39,31 g/butir (Putranto, Santoso dan Nurmeiliasari, 2010a). Penelitian tahun ke-3 adalah menyusun peta genetik (genom) ayam Burgo. Kesimpulan dari penelitian multi tahun ini adalah bahwa ayam Burgo betina memiliki potensi reproduksi yang luar biasa untuk pengembangan populasi. Dengan harga jual yang tinggi, ayam Burgo dapat menjadi komoditas unggulan bagi Desa Sumber RejoTransad yang bisa mendatangkan keuntungan bagi masyarakatnya. Kendala terbesarnya 
adalah pada prakteknya masyarakat beternak secara tradisional dan lebih memilih untuk memelihara ayam Burgo jantan sebagai ayam hias dan mengabaikan betina.

Desa Sumber Rejo-Transad, Kecamatan Bermani Ulu Raya, Kabupaten Rejang Lebong adalah lokasi yang ditargetkan untuk kegiatan pengabdian masyarakat. Tujuan jangka panjang pembinaan desa ini adalah untuk menjadikan Desa Sumber Rejo sebagai sentra produksi, pemasaran dan kegiatan penelitian ayam Burgo. Desa Sumber Rejo terletak di ketinggian diatas 1000 dpl memiliki luas wilayah 101 ha dengan jumlah penduduk 1496 jiwa, terdiri dari 327 kepala keluarga dengan mata pencaharian utama sebagai petani dan peternak. Dukungan vegetasi hutan dan lahan pertanian di desa ini mendukung kehidupan ayam Burgo di alam liar seperti yang dijelaskan dari hasil penelitian Nurmeiliasari (2003). Penelitian ini menemukan bahwa populasi ayam Burgo tertinggi adalah pada desa-desa dengan beberapa faktor ekologi seperti dukungan vegetasi yang memungkinkan mereka hidup bebas di alam. Hal ini sesuai dengan kondisi vegetasi desa Sumber Rejo-transad yang berada di kaki Bukit Barisan.

Sektor peternakan memperkuat perekonomian desa ini. Data kepemilikan ternak menunjukkan jumlah ayam kampung per kepala keluarga adalah berkisar 3-10 ekor, sapi potong yang berada dalam pemeliharaan masyarakat sekitar 203 ekor, selain itu juga terdapat ternak kambing (215 ekor), dan itik (150 ekor). Desa yang terletak di kaki Bukit Barisan ini memiliki beberapa kelompok tani untuk mewadahi kegiatan tani ternaknya. Mitra pada kegiatan pengabdian masyarakat untuk penembangan ayam Burgo ini adalah Kelompok Tani Makmur Jaya yang diketuai oleh bapak M. Yusuf. Latar belakang pendidikan petani peternak di kelompok ini adalah tamatan SD dan sebagian besar adalah tamatan SMP sampai SMA dan diploma tiga dengan rata-rata usia 21-50 tahun. Latar belakang pekerjaan anggota kelompok adalah petani peternak, seorang mahasiswa perawat kesehatan dan ketuanya yang juga merupakan seorang guru Sekolah Dasar. Pada pelaksanaan penelitian populasi dan distribusi ayam Burgo, kelompok ini merupakan mitra peneliti karena kepemilikan ayam Burgo. Kelompok ini memiliki pengetahuan dan keterampilan berkomunikasi dan pencarian informasi menggunakan media elektronik/IT . Anggota kelompok ini juga merupakan bagian dari petani peternak yang pernah mendapatkan penyuluhan dan pelatihan pencatatan ternak di tahun 2011. Kelompok ini telah menerapkan teknik pencatatan ternak dan memiliki rincian data ternak yang berada dalam pemeliharaan mereka. Untuk pemasaran dan mobilitas, anggota kelompok telah menggunakan alat transportasi yang mobil dan motor ditunjang dengan sarana infrastruktur desa yang memadai. Organisasi masyarakat ini menjadi mitra dan tempat diskusi bagi kelompok tani lainnya dan masyarakat di Desa Sumber Rejo-Transad, Kecamatan Bermani Ulu Raya.

Penelitian populasi ayam Burgo dan penyebarannya di sejumlah kabupaten dalam wilayah Provinsi Bengkulu di tahun 2001 dan 2010 menunjukkan hasil yang konsisten. Kabupaten Rejang Lebong memiliki populasi tertinggi dibandingkan kabupaten-kabupaten lainnya (Nurmeiliasari, 2003; Putranto, dkk, 2010a). 
Penurunan populasi yang signifikan terus terjadi. Di tahun 2001 tercatat populasi ayam Burgo di Kabupaten Rejang Lebong adalah 227 ekor (Nurmeiliasari, 2003). Jumlah ini menurun menjadi 98 ekor dalam kurun waktu sembilan tahun (Putranto, dkk, 2010a). Padahal ayam Burgo betina adalah petelur unggul yang memiliki produksi telur yang relatif tinggi yaitu 10-15 butir per periode bertelur atau kurang lebih 60 butir per tahun. Pengetahuan masyarakat peternak ayam Burgo di Desa Sumber Rejo-Transad masih sangat minim mengenai manajemen pakan, pemeliharaan dan kesehatan ayam.

Pengembangan ayam Burgo untuk tujuan komersial dan ilmu pengetahuan harus segera dirintis. Jika tidak, maka populasi ayam Burgo akan terus menurun dan dapat punah. Sangat disayangkan jika salah satu sumber keanekaragaman hayati Bengkulu ini tidak dikembangkan karena potensi dan peluang pengembangan ayam Burgo untuk menjadi salah satu komoditi unggulan yang memberikan keuntungan finansial bagi masyarakat terbentang luas.

\section{METODE PENGABDIAN}

Kegiatan pengabdian ini akan dilakukan dengan metode demplot. Pertama-tama warga yang memelihara ayam Burgo akan dikumpulkan dan diminta kesediaannya untuk melaksanakan pemeliharaan ayam Burgo bersama-sama di kandang kolektif. Selain milik warga, tim pelaksana pengabdian akan membeli 5 ekor ayam Burgo jantan dan 15 ekor ayam Burgo betina untuk memulai budidaya dengan sex ratio atau perbandingan jantan dan betina adalah 1:3, sesuai dengan yang disarankan oleh Afrizal (2007). Sistem bergulir juga diterapkan dalam kegiatan pengabdian ini dengan memberikan tanggung jawab kepada setiap anggota kelompok untuk menyisihkan pendapatan sejumlah Rp 30.000 per bulan atau Rp 1.000 per hari untuk keberlanjutan dan pengembangan kelompok budidaya ayam Burgo yang akan dibelanjakan untuk menambah jumlah kandang dan lain-lain yang berkaitan dengan kegiatan budidaya ayam Burgo dan penetasan.

Langkah-langkah yang akan dilakukan untuk memenuhi permintaan pasar akan ayam Burgo jantan sebagai ayam hias adalah dengan mengoptimalkan fungsi reproduksi betina. Ternak betina dan jantan akan dipelihara dengan sistem semi-intensif. Untuk tujuan tersebut, maka akan diadakan pelatihan, praktek dan pembimbingan untuk manajemen pakan dengan suplementasi EDK 27g/ekor/hari untuk ayam Burgo betina, perkandangan dan kesehatan untuk menciptakan betina dan pejantan Burgo dengan produktivitas tinggi. Suplementasi EDK akan meningkatkan produksi telur, berat telur dan fertilitasnya seperti yang direkomendasikan oleh Putranto, dkk (2010). Hal ini akan mendukung percepatan pertambahan populasi ayam Burgo.

Pelatihan Pengoperasian Mesin Tetas akan dilaksanakan untuk meningkatkan populasi ayam Burgo dalam waktu yang lebih singkat daripada mengeram secara alami. Sistem pemeliharaan tradisional dengan pengeraman telur oleh induk merupakan faktor lainnya yang menyebabkan fluktuasi populasi. Pemeliharaan betina dan jantan fertil saja 
tidak cukup untuk mempercepat pertumbuhan populasi ayam Burgo karena sifat mengeram menyebabkan terputusnya periode bertelur. Untuk memperpanjang periode bertelur, maka akan lebih baik untuk menggantikan fungsi mengeram induk dengan penggunaan mesin tetas sederhana.

Adapun urutan pelaksanaan kegiatan pengabdian ini adalah:

1. Sosialiasi kegiatan kepada masyarakat Desa Sumber Rejo Kecamatan Bermani Ulu Raya yang difokuskan kepada kelompok tani Makmur Jaya dan pemilik ayam Burgo serta masyarakat petani peternak desa.

2. Pembentukan dan pemilihan kepengurusan kelompok budidaya ayam Burgo binaan.

3. Persiapan kandang ayam Burgo usia produksi dan DOC, kelengkapan kandang dan pakan.

4. Pelatihan singkat penerapan mikronutrisi (EDK) di dalam pakan, manajemen pemeliharaan semi-intensif dan kesehatan unggas.

5. Penempatan unit mesin tetas otomatis.

6. Pelatihan singkat penggunaan mesin tetas dan operasional penetasan.

7. Uji coba dan pelatihan penetasan menggunakan telur ayam kampung, diikuti dengan pengumpulan telur, seleksi telur, penimbangan dan pembersihan telur. Penetasan telur dilakukan dengan mesin tetas otomatis, DOC yang baru lahir akan ditimbang dan diletakkan di kandang khusus DOC dengan pemanasan lampu.

8. Monitoring, evaluasi dan pandampingan kegiatan kelompok budidaya ayam Burgo Desa Sumber Rejo-Transad.

\section{HASIL DAN PEMBAHASAN}

\section{Realisasi Kegiatan}

Kegiatan pengabdian ini telah dapat direalisasikan, dimulai dengan sosialisasi kegiatan kepada masyarakat. Melalui kelompok tani Makmur Jaya maka telah diberikan bantuan kandang dan peralatannya untuk mencukupi keperluan pemeliharaan ayam Burgo serta mesin tetas untuk mendukung percepatan pertambahan populasi. Masyarakat juga telah mendapatkan beberapa penyuluhan yaitu penyuluhan mengenai pakan dan suplementasi ekstrak daun katuk, penyuluhan mengenai manajemen/administrasi keuangan kelompok dan penyuluhan mengenai manfaaat mesin tetas. Selain itu masyarakat juga mendapatkan kesempatan untuk praktek formulasi dan pencampuran pakan yang mengandung ekstrak daun katuk. Praktek penggunaan mesin tetas juga dilakukan agar masyarakat dapat memaksimalkan pemanfaatan mesin tetas yang telah dihibahkan kepada kelompok dalam upaya peningkatan populasi ayam Burgo.

Langkah yang dilakukan dalam pelaksanaan pengabdian dimulai dengan koordinasi dengan kepala desa dan peternak. Selanjutnya dilakukan pertemuan dengan masyarakat dan anggota kelompok tani untuk kesepakatan pelaksanaan dan sosialisasi rangkaian kegiatan yang akan dilakukan di desa ini. Kemudian masyarakat membuat kandang bagi 
ayam Burgo yang memenuhi kriteria perkandangan unggas yang baik dengan pendampingan oleh tim pengabdian kepada masyarakat Universitas Bengkulu. Setelah kandang terbentuk, masyarakat mendapatkan penyuluhan mengenai pakan dan manajemen pemeliharaan serta kesehatan unggas. Berikutnya masyarakat diberi pengetahuan berupa penyuluhan mengenai pemanfaatan mesin tetas untuk meningkatkan populasi ayam. Uji coba dan pelatihan penetasan juga dilakukan dengan menggunakan telur ayam kampung, diikuti dengan pengumpulan telur, seleksi telur, penimbangan dan pembersihan telur. Berikutnya dilakukan penetasan telur ayam Burgo dengan menggunakan mesin tetas. Penetasan telur dilakukan dengan mesin tetas otomatis, DOC yang baru lahir akan diletakkan di kandang khusus DOC dengan pemanasan lampu. Pendampingan dari tim pengabdian masyarakat yang terdiri dari Staf pengajar dan mahasiswa dilakukan selama pelaksanaan. Keseluruhan kegiatan terlaksana dengan adanya koordinasi yang baik antara tim pelaksana pengabdian masyarakat dengan masyarakat serta kelompok tani Makmur Jaya Desa Sumber Rejo Transad Kecamatan Bermani Ulu Raya, Kabupaten Rejang Lebong.

Kegiatan sosialisasi dan praktik pembuatan pakan berlangsung di rumah bapak Wito Winarno, Dalam kegiatan ini dihadiri anggota kelompok binaan. Pembuatan ransum diawali dengan pengenalan bahan pakan yang terdiri dari jagung giling, konsentrat, dedak dan ekstrak daun katuk (EDK). Bahan pakan dan kandungan nutrisinya di tampilkan pada Tabel 1. Adapun tujuan pembuatan pakan dalam bentuk ransum, agar masyarakat merespon untuk menerapkan IPTEK. Faktor pendorong lainya yaitu, di desa tersebut banyak sumber bahan pakan ternak seperti jagung dan bekatul dari bagian penggiligan padi yang tentunya kesemua bahan-bahan tersebut murah dan mudah didapat sehingga menguntungkan bagi usaha perkembangbiakan ayam Burgo di masyarakat.

Tabel 1. Kandungan Nutrisi bahan Penyusun Ransum

\begin{tabular}{|c|c|c|c|c|c|c|}
\hline Bahan pakan & Protein & $\begin{array}{c}\text { Energi } \\
(\mathrm{kkal} / \mathrm{kg})\end{array}$ & $\begin{array}{l}\text { SK } \\
(\%) \\
\end{array}$ & Lemak (\%) & $\mathrm{Ca}(\%)$ & $\begin{array}{c}\mathrm{P} \\
(\%)\end{array}$ \\
\hline Jagung giling $(\%)^{1}$ & 8,55 & 3105,66 & 2,42 & 2,97 & 0,37 & 0,44 \\
\hline Konsentrat layer $(\%)^{2}$ & 36 & 3500 & 7 & 5 & 12 & 1,6 \\
\hline Dedak Halus $(\%)^{1}$ & 10,45 & 1856,49 & 19,34 & 9,78 & 0,92 & 0,29 \\
\hline Mineral $(\%)^{3}$ & 0 & 0 & 0 & 0 & 32 & 10 \\
\hline Top Mix $(\%)^{4}$ & 0 & 0 & 0 & 0 & 0 & 0 \\
\hline
\end{tabular}

Sumber
: 1) Lab ilmu nutrisi dan teknologi pakan IPB 2005
2) Label kemasan konsentrat layer 581 gold PT Universal Agri Bisnisindo
3) Label kemasan mineral Medion Bandung
4) Label kemasan top mix Medion Bandung 
Tabel 2. Dari bahan-bahan diatas, dibuatlah ransum dengan susunan sebagai berikut

\begin{tabular}{|c|c|c|c|c|c|}
\hline Bahan Pakan & Bahan (\%) & Jumlah Bahan Pakan (kg) & Perhitungan & $\mathrm{Pk}(\%)$ & $\mathrm{Me}(\mathrm{kkal} / \mathrm{kg})$ \\
\hline Jagung giling (\%) & $40 \%$ & & $=40 / 100 * 8,55$ & 3,42 & 1242,264 \\
\hline Konsentrat (\%) & $30 \%$ & & $=30 / 100 * 36$ & 10,8 & 1050 \\
\hline Dedak halus (\%) & $30 \%$ & & $=30 / 100 * 10,45$ & 3,135 & 556,947 \\
\hline $\operatorname{Edk}(\%)$ & $0,05 \%$ & 0,5 & & & \\
\hline Total Bahan & $100 \%$ & $1050 \%$ & $0 \%$ & $1736 \%$ & $284921 \%$ \\
\hline
\end{tabular}

Dalam pelaksanaan kegiatan pengabdian pada masyarakat ini, ditemukan beberapa kendala yaitu sulitnya menemukan penjual ayam Burgo betina. Tim pengabdian membutuhkan waktu dan upaya yang lebih dalam mengumpulkan ayam Burgo yang akan menjadi objek kegiatan pengabdian masyarakat. Terjadi dua kali penyerahan ayam burgo untuk mencapai jumlah 20 ekor ayam Burgo. Dari Agustus hingga September, total ayam Burgo yang berhasil dikumpulkan dan dibeli oleh tim pengabdian masyarakat adalah 14 ekor yaitu 5 ekor betina fase produksi dan 6 ekor betina dara serta 3 ekor pejantan. Sampai dengan bulan Oktober kemudian jumlah total mencapai 20 ekor ayam Burgo dan 20 ekor anakan. Di akhir pertengahan bulan November jumlah totalnya menurun karena tingginya laju mortalitas. Selain itu, harga jual di pasaran cukup tinggi. Kedala lainnya selama pelaksanaan yaitu belum adanya pembagian tugas yang baik di dalam kelompok tani dalam kegiatan pemeliharaan bersama ayam Burgo. Hal ini menyebabkan kegiatan pemeliharaan semi intensif menjadi tidak maksimal. Data menyebutkan bahwa dari 15 ekor induk (ayam dara yang memasuki masa dewasa kelamin) dihasilkan total telur selama kurun waktu bulan Agustus sampai dengan November adalah 48 butir. Setelah ditetaskan maka dihasilkan 20 ekor anak ayam Burgo; artinya persentase telur yang menetas adalah $41 \%$. Jumlah ini relatif tinggi; artinya pemberian suplementasi ekstrak daun katuk telah dapat meningkatkan fertilitas telur. Dalam masa pemeliharaan anakan terjadi kematian yang cukup tinggi yaitu 50\%, sehingga total anakan dalam pemeliharaan saat ini adalah 10 ekor. DOC membutuhkan perhatian lebih selama pemeliharaan terkait pengaruh lingkungan yang mempengaruhi kondisi fisiologisnya. Sebagai contoh, Suhu lingkungan di Desa Sumber Rejo Transad berkisar antara $20-26^{\circ} \mathrm{C}$, suatu lingkungan yang berada di luar suhu normal lingkungan bagi DOC. Suhu normal tubuh ayam adalah $40-42^{\circ} \mathrm{C}$. Diperkirakan pemanasan di kandang DOC tidak memenuhi syarat bagi pertumbuhan DOC dan hal ini menjadi salah satu faktor yang menyebabkan laju mortalitas tinggi. Kematian juga dialami induk dan pejantan ayam Burgo yaitu sebanyak 6 ekor. Induk dara yang dipergunakan sebagai objek pengabdian sebagian didapatkan langsung dari hutan sedangkan sebagian lagi telah mengalami proses domestikasi sehingga proses adaptasi pada pemeliharaan semi intensif dengan pakan yang berbeda dengan pakan yang tersedia di hutan (disuplementasi ekstrak daun katuk) ini menyebabkan stress yang berakibat pada kematian pada sebagian induk. Saat ini jumlah ternak yang berada dalam pemeliharaan adalah 2 ekor pejantan, 7 ekor betina, 10 ekor anakan dan jumlah telur yang dalam proses penetasan adalah 15 butir. Jumlah ini menunjukkan bahwa telah tercapainya peningkatan populasi yang ditargetkan di 
awal kegiatan yaitu $10 \%$. Telah terjadi peningkatan populasi sebanyak $50 \%$ dan jumlah ini akan meningkat lebih tinggi jika tingkat kematian dapat ditekan dan pemeliharaan semi intensif terus diterapkan oleh masyarakat. Tim pelaksana kegiatan masyarakat optimis bahwa tujuan jangka panjang kegiatan ini dapat tercapai. Desa Sumber Rejo Transad akan bisa menjadi sentra produksi ayam Burgo di Kabupaten Rejang Lebong dan Provinsi Bengkulu.

Selama pelaksanaan kegiatan ini, masyarakat peternak mengikuti dengan rasa ingin tau yang tinggi. Diskusi yang tercipta menunjukkan proses pencernaan informasi. Di tahap awal penerapan, diketahui masyarakat peternak sangat tertarik untuk dapat berpartisipasi aktif dalam menciptakan sumber pendapatan baru melalui pemeliharaan semi intensif ayam Burgo. Beberapa kendala yang ditemui selama masa pemeliharaan membuat masyarakat cenderung menunjukkan niat untuk memelihara ayam Burgo dengan mengumbar. Mereka lebih cenderung mengumbar ternak pada siang hari dengan pemberian pakan perlakuan pada pagi dan sore hari. Tim pelaksana kegiatan menekankan agar peternak jangan surut meskipun menemui kendala dan tetap menjaga kerjasama yang solid yang sudah tercipta. Meskipun belum ada pemasukan kelompok dari penjualan ayam Burgo, tetapi animo masyarakat sudah tampak dari minat masyarakat desa untuk datang dan melihat langsung pemeliharaan semi intensif ini.

\section{Analisis Biaya dan Pendapatan Usaha}

Selama masa pengabdian biaya pemeliharaan dan pemberian pakan ayam Burgo ditanggung sepenuhnya oleh tim pengabdian. Adapun perincian butir anggaran lengkap dengan harga satuan untuk dapat dilihat pada Tabel 3. Alokasi biaya operasional pemeliharaan ayam Burgo terbesar adalah biaya pembelian bakalan ayam. Harga ayam jantan mencapai Rp 500.000 dan betina Rp 350.000. hal ini disebabkan oleh sulitnya mendapatkan ayam jenis lokal Bengkulu ini. Selain itu, biaya yang dikeluarkan adalah biaya pembuatan kandang dengan ukuran 3 meter x 4 meter atau seluas $12 \mathrm{~m}^{2}$. Kandang ini dirasa sudah cukup memadai untuk permulaan usaha. Selanjutnya adalah biaya peralatan kandang, seperti tempat pakan dan minum.

Kegiatan pengabdian yang juga memberikan fasilitas mesin tetas mengeluarkan biaya sebesar Rp 800.000 untuk pengadaan mesin tetas sederhana dengan sistem pengatur suhu otomatis. Selain itu biaya peralatan dan perlengkapan yang dikeluarkan adalah biaya pembuatan kandang untuk DOC ukuran kapasitas 20 anakan (DOC), brooder, pakan (jagung giling, konsentrat, dan EDK) selama 1 bulan, dan obat-obatan. Jadi total biaya yang dikeluarkan untuk memulai usaha pemeliharaan ayam Burgo adalah sebesar Rp 16.230.000,-.

Selama kegiatan pengabdian berlangsung, belum dihasilkan penjualan terhadap ayam Burgo, sehingga penerimaan masih nihil. Oleh karena itu perhitungan pendapatan belum bisa dilakukan. Sehingga analisis hanya bisa dilakukan sampai tahapan perhitungan biaya operasional dan investasi. Disini yang tergolong investasi adalah Pembuatan 
Kandang (Pembesaran dan DOC), Peralatan Kandang, Mesin Tetas Otomatis, Bakalan Ayam Burgo, dan Brooder. Sedangkan komponen lainnya masuk ke dalam kategori biaya operasional.

Tabel 3. Rincian Biaya Operasional dan Investasi

\begin{tabular}{|c|c|c|c|c|}
\hline No & Rincian & Unit Cost & $\begin{array}{l}\text { Jumlah } \\
\text { (Rp) }\end{array}$ & $\%$ \\
\hline \multirow[t]{9}{*}{1} & Peralatan & & & 48,86 \\
\hline & $\begin{array}{l}\text { Peralatan kandang (tempat pakan dan } \\
\text { tempat minum) }\end{array}$ & $6 \times 15.000$ & 90.000 & \\
\hline & Mesin tetas otomatis & 1 unit $\times 800.000$ & 800.000 & \\
\hline & $\begin{array}{l}\text { Pembuatan } 1 \text { unit kandang ayam dewasa } \\
\text { kapasitas } 50 \text { ekor ukuran } 3 \times 1 \mathrm{~m}\end{array}$ & 1 unit $x 4.500 .000$ & 4.500 .000 & \\
\hline & $\begin{array}{l}\text { Pembuatan } 1 \text { unit kandang ayam DOC } \\
\text { kapasitas } 20 \text { ekor ukuran } 1 \mathrm{X} 1.5 \mathrm{~m}\end{array}$ & 1 unit x 600.000 & 600.000 & \\
\hline & $\begin{array}{l}\text { Pakan + EDK selama } 1 \text { bulan untuk } 20 \text { ekor } \\
\text { ayam }\end{array}$ & $\begin{array}{c}0.1 \mathrm{~kg} \times 20 \text { ekor x } 30 \text { hari } \\
\text { x } 8000\end{array}$ & 480.000 & \\
\hline & Brooder & 1 unit $\times 260.000$ & 260.000 & \\
\hline & Obat-obatan & 200.000 & 200.000 & \\
\hline & Jumlah (2) & & 7.930 .000 & \\
\hline \multirow[t]{4}{*}{2} & Bahan & & & 47,75 \\
\hline & Beli 5 ekor ayam Burgo jantan & 5 ekor $x 500.000$ & 2.500 .000 & \\
\hline & Beli 15 ekor ayam Burgo betina & 15 ekor x 350.000 & 5.250 .000 & \\
\hline & $\begin{array}{ll} & \text { Jumlah (3) } \\
\end{array}$ & & 7.750 .000 & \\
\hline \multirow[t]{5}{*}{3} & Transportasi & & & 3,39 \\
\hline & Ongkos transport belanja perlengkapan dan b & רan & 550.000 & \\
\hline & Total Biaya + Investasi $(1+$ & & 16.230 .000 & 100 \\
\hline & Penerimaan & & $\mathbf{0}$ & \\
\hline & Pendapatan & & - & \\
\hline
\end{tabular}

\section{KESIMPULAN DAN SARAN}

\section{Kesimpulan}

Dari kegiatan pengabdian pada masyarakat ini dapat diambil kesimpulan sebagai berikut :

1. Masyarakat memperoleh tambahan pengetahuan tentang sistem perkandangan dan kelengkapannya.

2. Masyarakat mendapatkan pengetahuan mengenai prinsip kerja mesin tetap dan cara penggunaannya.

3. Masyarakat memahami urgensi peningkatan populasi ayam Burgo dan manfaat ekonomi yang bisa didapatkan karena budidaya ayam Burgo dapat menjadi sumber pendapatan bagi masyarakat.

4. Masyarakat masih dalam proses untuk dapat disiplin menerapkan sistem pemeliharaan ayam Burgo secara semi intensif.

5. Masyarakat perlu meningkatakan frekuensi latihan penggunaan mesin tetas agar keterampilannya meningkat. Hal ini akan menurunkan faktor resiko rendahnya keberhasilan penetasan. 
6. Keberlanjutan usaha pengembangbiakan sangat ditentukan oleh kekompakan kelompok tani.

7. Belum terbentuknya kerjasama dengan pihak penampung ayam hias dikarenakan jumlah yang ada dalam pemeliharaan masih rendah.

\section{Saran}

1. Keberlanjutan usaha pengembangbiakan sangat ditentukan oleh kekompakan kelompok tani.

2. Peternak yang telah mengikuti penyuluhan dan pelatihan diharapkan dapat bekerjasama dan berbagi pengalaman dengan peternak lain sehingga lebih banyak peternak yang tertarik untuk membudidayakan ayam Burgo sebagai sumber pendapatan selain kegiatan bertani dan beternak yang sudah dilakukan saat ini.

\section{DAFTAR PUSTAKA}

Afrizal, 2007, Performans Pertumbuhan Ayam Burgo, Ayam Kampung dan Hasil Persilangannya. Skripsi, Jurusan Peternakan, Fakultas Pertanian, Universitas Bengkulu.

Dapriansyah, E., 2001, Pendugaan Populasi dan Penyebaran Ayam Burgo di Kecamatan Padang Ulak Tanding dan Kecamatan Kota Padang Kabupaten Rejang Lebong, Skripsi, Jurusan Peternakan, Fakultas Pertanian, Universitas Bengkulu.

Lisaudin, O., 2001, Kajian Populasi Ayam Burgo dan Hubungannya dengan Ayam Kampung, Skripsi, Jurusan Peternakan, Fakultas Pertanian, Universitas Bengkulu.

Nurmeiliasari, 2001, Populasi dan Penyebaran Ayam Burgo serta interaksinya dengan Berbagai Komponen Ekologi (Studi Kasus di Kecamatan Curup dan Kepahiang Kabupaten Rejang Lebong). Skripsi, Jurusan Peternakan, Fakultas Pertanian, Universitas Bengkulu.

Nurmeiliasari, 2003, Populasi dan Penyebaran Ayam Burgo serta Interaksinya dengan Berbagai Faktor Ekologi (Studi Kasus di Kecamatan Curup dan Kepahiang, Kabupaten Rejang Lebong, Bengkulu). Jurnal Raflesia UMB Vol:V (2) : 52-55.

Putranto, H.D., Santoso, U., Warnoto, Nurmeiliasari, 2010a. Kajian Konservasi: Populasi, Tampilan Reproduksi dan Potensi Domestikasi Ayam Burgo Plasma Nutfah Endemik Bengkulu, Proposal Hibah Penelitian Strategis Nasional Lanjutan Tahun ke-2, Lembaga Penelitian Universitas Bengkulu.

Putranto, H.D., Santoso, U., Fenita, Y., Nurmeiliasari., Zueni, A., Gibson, B. 2010b. A Study on Population Density and Distribution Pattern of Domesticated Bengkulu Native Burgo Chicken. Media Kedokteran Hewan Vol. 26 (3) edisi September 2010 in press. 